\title{
分婏後に外転神経麻痺を併発した副鼻腔炎例
}

\author{
杉田 明美・釸持＼cjkstart睦・佐藤 成樹 \\ 宮本 康裕・肥塚泉*
}

\section{A Case of Postpartum Chronic Sinusitis with Abducens Nerve Palsy}

\author{
Akemi Sugita, Mutsumi Kenmochi, Shigeki Sato and Yasuhiro Miyamoto \\ (Yokohama City Seibu Hospital, St. Marianna University School of Medicine) \\ Izumi Koizuka \\ (St. Marianna University School of Medicine)
}

\begin{abstract}
Abducens nerve palsy during pregnancy is an extremely rare condition. The case described herein involved a 26 -year-old woman presenting with postpartum chronic sinusitis accompanied by abducens nerve palsy. The patient had complained of sinusitis, but did not receive treatment because of her pregnancy. She complained of headache and fever before delivery, and exhibited diplopia just after delivery. On admission, meningitis and chronic sinusitis were diagnosed. She was treated with antibiotics and sinus surgery, which improved her diplopia. Thereafter, meningitis resolved gradually.

Involvement of the abducens nerve in isolation might be attributable to progressive thrombophlebitis affecting the sphenoid sinus, or direct compression by the thickened dura due to meningitis.

There are several reports in the literature concerning otolaryngological conditions during pregnancy. In our case, it appeared that chronic sinusitis worsened because of hormonal changes during pregnancy in addition to the lack of treatment. This case suggests that careful diagnosis and proper treatment of chronic sinusitis are needed even during pregnancy to avoid serious complications such as meningitis.
\end{abstract}

Key words : sinusitis, abducens nerve palsy, pregnancy, meningitis

はじめに

妊娠により鼻・副鼻腔炎が増悪することはよく知られ ている12). しかし，妊娠による副鼻腔炎の増悪に外転神 経麻痺が伴ら症例はまれである。われわれは，妊娠中に 慢性副鼻腔炎の急性増悪をきたし，さらに分婏直後に外 転神経麻痺を併発した症例を経験した。本症例における 慢性副鼻腔炎の急性増悪ならびに外転神経麻痺の原因に ついて文献的考察を加え報告する。

\section{症例}

症例 : 26 歳, 女性.

主訴：複視.

家族歴・既往歷：特記すべき事項なし.

現病歴 : 2003 年 4 月下旬, 左上顎う歯を指摘されたが 妊娠中 ( 9 力月) のため, 歯科にて消毒だけを行っていた. 5 月上旬から多量の膿性鼻漏が出現し, 近医耳鼻咽喉科 にて副鼻腔炎を指摘されたが，妊娠中のため治療は行わ れなかった. また患者も通院を自己中断していた. 6 月 上旬, 前額部, 左眼周辺, 左㚘頁部および後頭部痛が出現 
し, $38^{\circ} \mathrm{C}$ 前後の発熱を繰り返すようになった。 6 月 12 日 に破水したため，近医産婦人科に入院となった。同日， セフメタゾールナトリウム（1 g/日）の点滴が 1 週間行 われた。 13 日に正常経臸分婏にて出産. 分婏室に入った 時点で左眼の違和感が存在しており, 出産直後, 複視に 気付いた。16 日に近医眼科を受診し，シアノコバラミン 点眼薬，メコバラミン，アデノシン三リン酸二ナトリウ ムを処方された。1 8 日に複視精查加療目的にて当院神経 内科に紹介入院となった。頭部 MRI にて副鼻腔炎を認め たため，6月 19 日当科紹介受診となった。

入院時所見：

身体学的所見; 体温 $37.0^{\circ} \mathrm{C}$, 頭痛（前額部, 左眼周 辺，左頓部および後頭部）あり。

神経学的所見; 意識清明. 左外転神経麻痺 $(-4)$ を認 めたが，その他の中枢神経症状なし。

血液所見; 赤血球 451 万 $/ \mu 1$, 白血球 $8300 / \mu 1$, 血小板

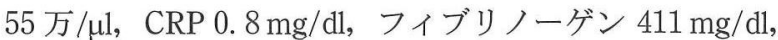
$\mathrm{TAT} 41.3 \mathrm{ng} / \mathrm{ml}$ （正常值 $<3.2$ ）。凝固系の軽度上昇は妊 娠による影響と考えられた。

髄液所見; 細胞数 $800 / 3 / \mathrm{mm}^{3}$ (単球 $54 \%$, 多核球 46 $\%)$ ，総蛋白 $54 \mathrm{mg} / \mathrm{dl}$ ，糖 $39 \mathrm{mg} / \mathrm{dl}$. 䯣液所見より細菌性 髄膜炎と診断された。
鼻内所見；下鼻甲介に発赤，腫脹を認訲。左側に凹 の鼻中隔弯曲があり，左中鼻甲介が圧排され，左中鼻道 は閉塞していた。左中鼻道前方に膿の付着を認めた。な お，ポリープは認められなかった。

画像所見（頭部 MRI）；T1 強調画像にて等信号，T2 強 調画像にて周囲が高信号，内部が等信号を示す病変が左 上顎洞，左後部篩骨蜂巣，左蝶形骨洞に充満しており， 慢性副鼻腔炎の急性増覀と診断された（図 1)。海綿静脈 洞の MRI 画像では，T1 と T2 そて，左の海綿静脈洞の桩 大および輝度の増強を軽度認めたため，左海綿静脈洞炎 の可能性も示唆された。なお, 拡散強調画像およびFLAIR 法にて高信号を示す梗塞巣を認めたが，左外転神経麻痺 とは病巣が反対側であり，所見が一致しないため脳幹部 梗塞が今回の外転神経麻痺の原因とは考えがたいと判断 した.

経過：入院後経過を図 2 に示す。エダラボンおよびカ ルバペネムによる点滴治療にて髄液細胞数の減少を認め たが（細胞数 $301 / 3 / \mathrm{mm}^{3}$ (単球 $98 \%$ ，多核球 $2 \%$ )，総 蛋白 $35 \mathrm{mg} / \mathrm{dl})$ ，眼球運動制限の改善は認められなかっ た。入院時頭痛を訴えていたが，上記点滴治療を開始し 5 日目頃より改善傾向を認めた。6月 19 日，神経内科よ り耳鼻咽喉科への対診依頼を受け，髄膜炎などの全身状

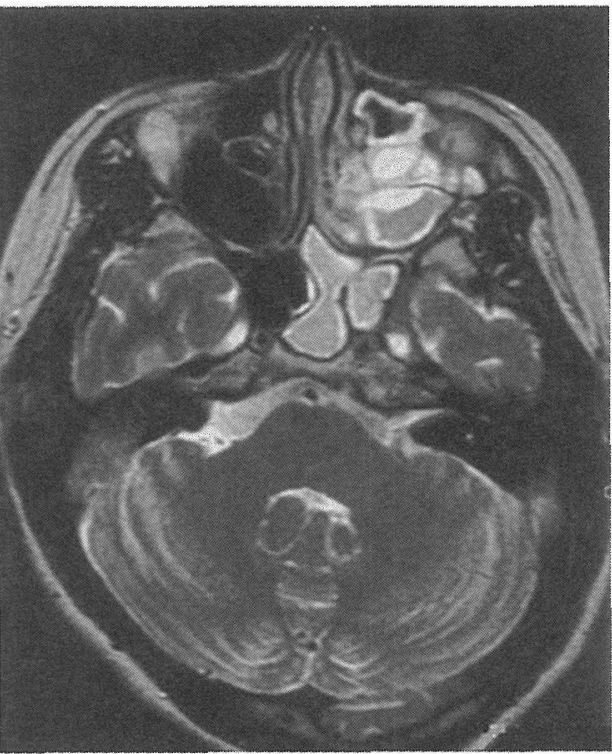

$\mathrm{T} 2$ 強調画像

図 1 頭部 MRI（副鼻腔） 左上顎洞, 左後部篩骨蜂巣, 左蝶形骨洞内に病変を認める. 


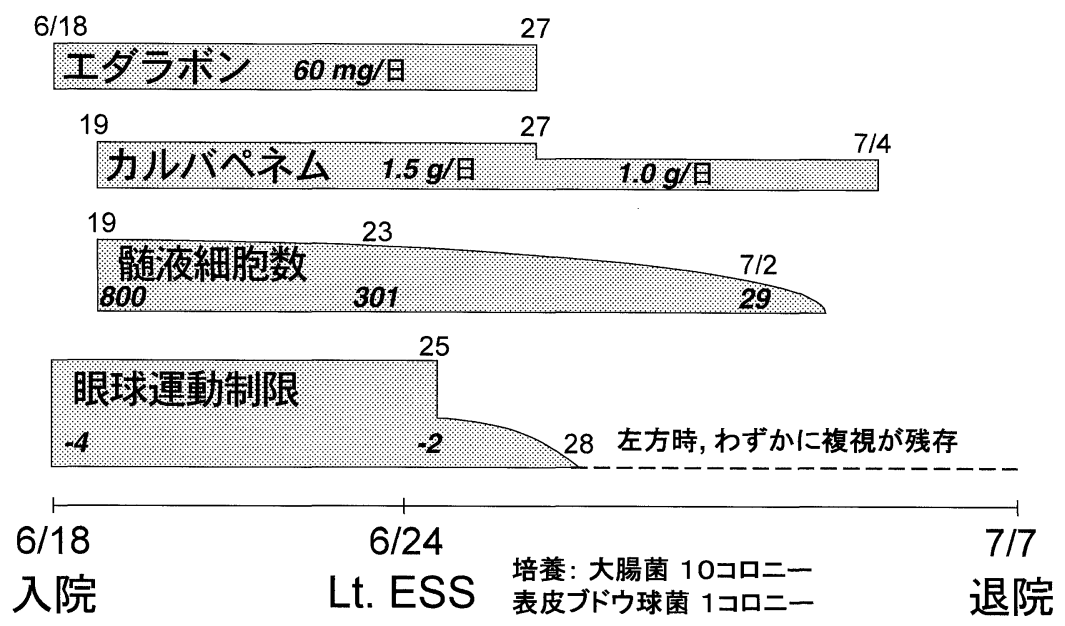

図 2 入院後経過

手術翌日より複視の著明な改善を認めた。

Lt. ESS : 左鼻内内視鏡下副鼻腔根本術

態が改善した 6 月 24 日, 全身麻酔下にて鼻中隔弯曲矯正 術および左鼻内内視鏡下副鼻腔根本術を施行した，術中 所見としては，左中鼻道は狭窄していたが左鼻腔内にポ リープは認められなかった. 第 1 ，第 2 基板を開放する と, 粘膜の肥厚とともに膿貯留が認められ, 自然口から 左上顎洞を開放すると膿が充満していた，左鼻前頭管の 閉塞は認められなかった。最後に，篩骨洞経由から左蝶 形骨洞を開放すると, 洞内の粘膜は強く肥厚していた. 易出血性であったため, 骨の状態, 特に骨欠損について は詳細な観察はできなかった。手術翌日には眼球運動制 限は著明に改善を認めた. 6 月 28 日には左方時のわずか な複視が残存したが，眼球運動制限は消失を認めた。な お, 上顎洞膿の培養からは, 大腸菌 10 コロニー, 表皮ブ ドウ球菌 1 コロニーが検出された. 7 月 2 日の髄液所見 では細胞数 $29 / 3 / \mathrm{mm}^{3}$ (単球 $100 \%$ ), 総蛋白 $29 \mathrm{mg} / \mathrm{dl}$, 糖 $55 \mathrm{mg} / \mathrm{dl}$ と改善を認めた. 左上顎洞炎の原因と考えら れる左上顎根尖性歯周組織炎に対し， 7 月 3 日歯科にて 左上顎第 1 日歯を抜歯, 7 日に退院となった. 退院 3 力月 後には複視も完全に消失した。

\section{考察}

1）妊娠による副鼻腔炎の増悪

妊娠により，鼻・副鼻腔炎が増悪することが知られて いる112). Dykewicz ら ${ }^{1)}$ は典型的には妊娠 2 力月目で鼻閉 などの鼻症状が出現すると報告している，妊娠による鼻 炎や副鼻腔炎が増悪する原因として，妊娠によるホルモ
ンバランスの変化が挙げられる. エストロゲンの増加は 鼻粘膜肥厚を引き起こし3)，プロゲステロンに感作され た鼻粘膜ではヒスタミンレセプターや好酸球の増加が起 こる ${ }^{4)}$. 胎盤成長ホルモンはプロゲステロンに類似した 作用をもつといわれている5)。 また，妊娠中のストレス によって，下鼻甲介の充血や鼻粘膜腫脹をきたすという 報告むある6).

さらに妊娠中には一般的に免疫能が低下しており, 感 染に対する抵抗力が減弱している．本症例の主な起炎菌 は大腸菌であった，嫌気性菌による副鼻腔炎は慢性例に 多く, 逆に急性副鼻腔炎では好気性菌が多い7).さらに, 免疫能低下を起こしている例では，グラム陰性桿菌の感 染が多いことが知られている ${ }^{8)}$. 本症例において認めら れた大腸菌を起因菌とする慢性副鼻腔炎の増悪は，妊娠 を理由に積極的な治療が行われなかったことに加え，妊 娠に伴う一過性の免疫能低下が原因により生じたものと 考えられる。

2）髄膜炎の感染経路

鼻性頭蓋内合併症の感染経路には，副鼻腔骨壁の板間 静脈や粘膜内小静脈を介するもの，骨欠損や骨病変に由 来するもの，それから眼窩など隣接器官を介する経路が ある ${ }^{9)}$. 本症例の髄膜炎の感染経路としては, 上顎洞, 篩骨洞，蝶形骨洞のいずれかの炎症が原因となり，板間 静脈を介して惹起された可能性が考えられる。脳幹部 クナ梗塞は，副鼻腔炎の増悪により板間静脈を介して敗 血症となり，これを契機として生じた塞栓が原因として 


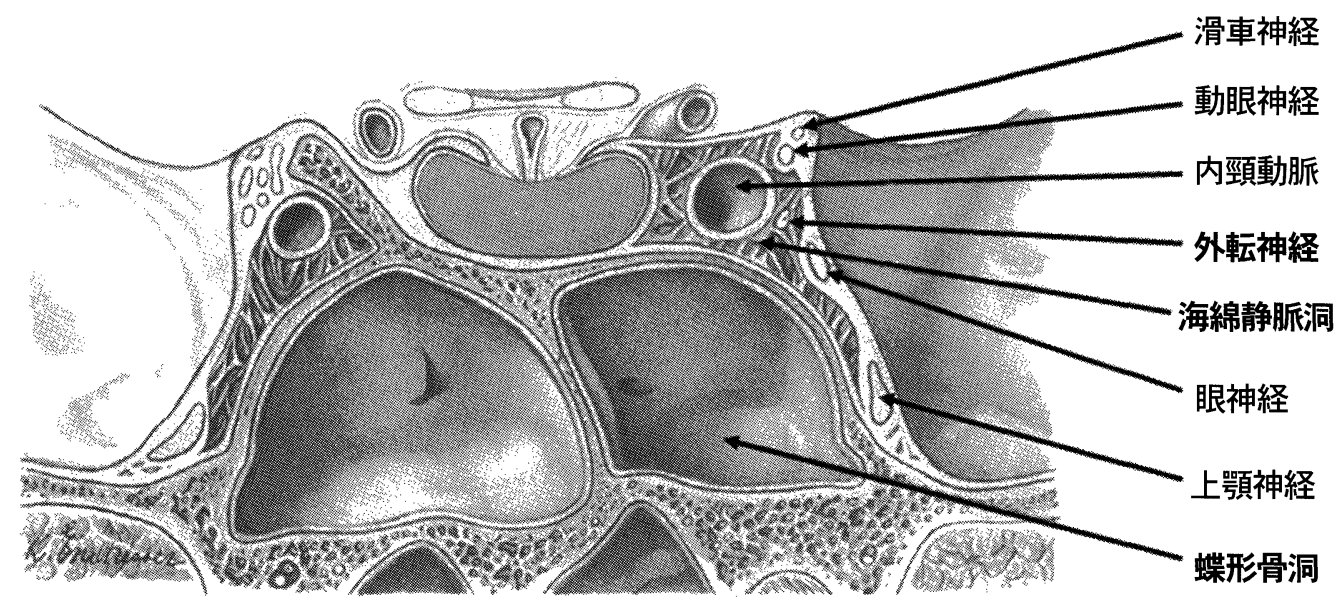

図 3 海綿静脈洞周辺の解剖

(Werner Platzer 編集，佐藤達夫訳：ペルンコップ臨床局所解剖学アトラス第 3 版. 医学書院，1995 11 より引用.)

生じた可能性が考えられる.

3）外転神経麻痺の原因

妊娠中に外転神経麻痺を発症した例は過去に数例報告 があるが，いずれも副鼻腔炎を呈してはおらず，原因不 明のものであった ${ }^{10)}$. 蝶形骨洞炎が海綿静脈洞血栓症へ 波及し，外転神経麻痺を呈することはしばしば認められ る. 蝶形骨洞は海綿静脈洞に隣接し, 骨壁が薄いため容 易に炎症が波及する（図 3） 11）。海綿静脈洞の内部には， 外転神経が側壁に沿って走行しているため, 海綿静脈洞 炎の初期症状として複視が報告されている ${ }^{12)}$. 海綿静脈 洞血栓症の場合, 血检形成後, 数日から 1 週間以内では, $\mathrm{T} 1$ 強調画像で高信号を示すようになる ${ }^{13)}$. 本症例では MRI 上 T1 強調画像で高信号を示してはいたが軽度であ り, 海綿静脈洞病変は副鼻腔炎から波及した炎症性変化 であり，明らかな血栓形成にはいたっていなかったもの と推定した。 ただ，海綿静脈洞炎では多彩な眼症状をき たす場合が多く報告されているが 14)，本症例は外転神経 の単独の麻痺であるため, 今回の外転神経麻痺をきたし た別の機序として, 髄膜炎もしくは蝶形骨洞からの直接 浸潤により硬膜の肥厚をきたし，それにより直接，外転 神経が圧迫された可能性も否定できない，上述したよう に妊娠中に副鼻腔の感染が増悪したところに, 出産時の いきみによる一時的な血圧上昇が加わり, 微小静脈が拡 張し炎症が波及し, 鼻性頭蓋内合併症を併発するにい たった可能性も考えられた。

4）治療の必要性

妊娠中の X 線単純撮影，CT などによる画像診断や薬
剂投与による治療は，胎児の催奇形性の可能性があるた め敬遠される傾向にある。しかしながら，画像診断によ る放射線の被曝に関しては，ヒトにおいて受精後 6 週以 降は, 胎児の催奇形性や死亡をきたす可能性は非常に少 なく, 妊娠 6 週までにおいては, 計算上, 頭部単純では 1250 回, 頭部 CT では 100 回以上撮影しないと胎児への 異常が現れるまでにはいたらないとされている ${ }^{15)}$. 薬剤 投与に関しても慎重投与を要するが，鼻炎に対する局所 のステロイド点鼻薬 ${ }^{16)}$ や, 抗生剤でも $\beta$-ラクタム薬 (ペ ニシリン系, セフェム系） は比較的危険性が少ないとい う報告がある17)18)。しかし, その場合, 重要器官が発生, 分化がする時期を可能であれば避け, 妊娠 16 週以降が望 ましいとされる16). ただし，危険性はない，などと安易 に患者にいうことも避けるべきであり, 十分な説明と納 得の上で検查や治療は行らべきと思われる.

本症例では, 副鼻腔炎を指摘されながらも妊娠を理由 に適切な治療が行われずその結果, 髄膜炎をきたすまで にいたった. 髄膜炎が進行すれば神経学的後遺症を残す 可能性や，死にいたる可能性もあるので本症例に対して は鼻処置を頻回に行い, 妊娠時期を考慮した上で, 必要 があれば頭部単純撮影を行い，重度の副鼻腔炎を疑った 場合は，試験的上顎洞穿刺および洗浄 ${ }^{17)}$ を積極的に行う ことも考慮すべきであったと思われる.

手術時期については, 本症例では神経内科と相談の上, 2 回目の髄液検査にて髄膜炎の改善を確認した後に手術 を行うこととなった．髄膜炎が副鼻腔炎によるものと診 断されたら手術はなる心゙く早期に行う必要がある.しか 
し, 髓膜炎により悪化した全身状態の改善も重要であり, それも考慮した上で手術時期を決定することが望ましい と思わ机た。

\section{まとめ}

1. 分婏直後に外転神経麻痺を併発した副鼻腔炎の1症 例を経験した。

2. 慢性副鼻腔炎の急性増悪は, 妊娠を理由として副鼻 腔炎の治療が行われなかったことが原因となり，さらに 妊娠によるホルモンバランスの変化により惹起されたも のと考えられた。

3. 外転神経麻盘の原因として, 蝶形骨洞炎の海綿静脈 洞への波及，あるいは髄膜炎により硬膜肥厚が起こり， 神経が圧迫された可能性が考えられた。

4. 妊娠中でも副鼻腔炎の診断および治療を急っては ならないことを常に念頭に置くべきである.

本論文の要旨は, 日本耳鼻咽喉科学会地方部会 第 126 回 耳鼻 咽喉科・頭頸部外科学術講演会（2003 年 12 月 6 日，横浜）に おいて口演した。

\section{参考文献}

1) Dykewicz MS, Fineman S, Skoner DP, et al. : Diagnosis and management of rhinitis: complete guidelines of the joint task force on practice parameters in allergy, asthma and immunology. Ann Allergy Asthma Immunol $81: 478 \sim 518,1998$.

2) Sobol SE, Frenkiel S, Nachtigal D, et al. : Clinical manifestations of sinonasal pathology during pregnancy. J Otolaryngol $30: 24 \sim 28,2001$.

3) Taylor $\mathrm{M}$ : The nasal vasomotor reaction. Otolaryngol Clin North Am $6: 645 \sim 654,1973$.

4) Hamano N, Terada N, Maesako KI, et al. : Expression of histamine receptors in nasal epithelial cells and endothelial cellsthe effects of sex hormones. Int Arch Allergy Immunol 115 : $220 \sim 227,1998$.

5) Ellegård E, Oscarsson J, Bougoussa M, et al. : Serum level of placental growth hormone is raised in pregnancy rhinitis. Arch Otolaryngol Head Neck Surg $124: 439 \sim$ 443, 1998.

6) Mabry RL: Rhinitis of pregnancy. South Med J 79:965 971, 1986.

7) Brook I : Bacteriology of acute and chronic sphenoid sinusitis. Ann Otol Rhinol Laryngol $111: 1002 \sim$ 1004, 2002.

8) Mevio E, Benazzo M, Quaglieri S, et al. : Sinus infection in intesnsive care patients. Rhinology $34: 232 \sim 236,1996$.

9）佐藤成樹, 上杉恵介, 菊地原基敬, 他 : 鼻性脳膿瘍の一症 例. 耳鼻臨床 補 $9: 202 \sim 209,1987$.

10) Fung TY and Chung TK : Abducens nerve palsy complicating pregnancy: a case report. J Obstet Gynecol Reprod Biol 83 : $223 \sim 224,1999$.

11）佐藤達夫訳：頭部・頸部、ペルンコップ臨床局所解剖学了 トラス第 3 版（Werner Platzer 編集）。第一巻. 114 頁，医 学書院, 東京, 1995.

12) Deans JA and Welch AR : Acute isolated sphenoid sinusitis: a disease with complications. J Laryngol Otol 105:1072 1074, 1991.

13) Savino PJ, Grossman RI, Schatz NJ, et al. : High-field magnetic resonance imaging in the diagnosis of cavernous sinus thrombosis. Arch Neurol $43: 1081 \sim$ 1082, 1986.

14) Sofferman RA : Cavernous sinus thrombophlebitis secondary to sphenoid sinusitis. Laryngoscope $93: 797 \sim 800,1983$.

15）吉田 純：妊娠と知らずに $X$ 線検査を受けても必ず奇形が 生まれるわけではない! 治療増刊号 $85: 324 \sim 327,2003$.

16）前田陽一郎，市村恵一：アレルギー性鼻炎妊婦の薬物療法. アレルギー科 $7: 340 \sim 345,1999$.

17) Sorri M, Hartikainen-Sorri AL and Kärjä $J$ : Rhinitis during pregnancy. Rhinology $18: 83 \sim 86,1980$.

18）松田静治：妊産婦・胎児への安全性からみた抗菌薬の分類. 感染と抗菌薬 $6: 251 \sim 258,2003$.

原稿受付: 平成16年 8 月 16 日

原稿採択 : 平成16年10月 6 日

別刷請求先：杉田明美

T241-0811 神奈川県横浜市旭区矢指町1197-1

聖マリアンナ医科大学横浜市西部病院耳鼻咽喉科 